\title{
ADSORPTION OF NICKEL IONS FROM PETROLEUM WASTEWATER ONTO CALCINED KAOLIN CLAY: ISOTHERM, KINETIC AND THERMODY- NAMIC STUDIES
}

\author{
Alexander Asanja Jock ${ }^{* 1}$, Anietie Ndarake OKON ${ }^{1}$, UChechukwu Herbert OfFor ${ }^{1}$, \\ FESTUS THOMAS ${ }^{2}$, AND EDMOND OKWUDILICHUKWU AGBANAJE ${ }^{3}$ \\ ${ }^{1}$ Department of Chemical and Petroleum Engineering, University of Uyo, PMB 1017, Uyo, NIGERIA \\ ${ }^{2}$ Department of Engineering Infrastructure, National Agency for Science and Engineering Infrastructure \\ (NASENI), Idu Industrial Area, PMB 391, Garki-Abuja, NIGERIA \\ ${ }^{3}$ Chemical and Petroleum Technique, Department of Science Laboratory Technology, University of Jos, \\ PMB 2084, Jos, NIGERIA
}

\begin{abstract}
The removal of nickel ions onto calcined kaolin clay using a batch adsorption technique was conducted. The effect of the adsorbent mass, contact time and temperature on the removal process was investigated. The calcined kaolin clay was characterized using X-ray fluorescence (XRF) and Fourier-Transform InfraRed spectroscopy (FTIR). The adsorption data was analyzed by isotherm, kinetic and thermodynamic studies. The major chemical components in the clay are alumina (41.14 wt \%) and silica (53.16 wt \%). FTIR showed that the functional groups of aluminium monoxide (Al-O) and silicon monoxide (Si-O) are present in the clay. The study yielded a removal efficiency of $89.89 \%$ for nickel ions at $25^{\circ} \mathrm{C}$. The adsorption process appeared to follow a Freundlich isotherm and pseudo-second order kinetics were found to be in good agreement with the experimental data. The thermodynamics of the rate processes showed the adsorption of nickel ions to be endothermic and negative values of Gibbs free energy indicated the spontaneity of these processes. This proves that calcined kaolin clay is a good material for the removal of nickel ions from the wastewater produced by petroleum refineries.
\end{abstract}

Keywords: Adsorption, Kaolin, Nickel, Wastewater

\section{Introduction}

Environmental pollution is an anthropogenic phenomenon and mainly a result of industrialization. The contamination of bodies of water by the indiscriminate disposal of heavy metals has led to serious threats to humans as well as aquatic and living creatures. Nickel compounds are highly toxic contaminants and are emitted into the environment from various industries, e.g. mining, metal coatings, batteries, chemical, tanneries, etc., in quantities that pose risks to human health [1].

Many wastewater treatment methods have been introduced to control water pollution such as chemical precipitation, ion exchange, electrodialysis, reverse osmosis as well as membrane filtration and adsorption. Adsorption is one of the most efficient techniques due to its simplicity and affordability, moreover, it is more feasible even at low concentrations of heavy metal ions [2]. The adsorbent used for the adsorption process is of organic origin, e.g. activated carbon and biosorbents, or mineral origin, e.g. natural zeolite, calcium silicate powder and natural clay

*Correspondence: alsanja@gmail.com
[3]. Activated carbon is the most commonly used adsorbent for wastewater treatment but due to it expense, lowcost alternatives such as clay, coal, fly ash, peat, siderite, agricultural wastes and charcoal are being developed. Low-cost adsorbents are those that require little processing and are abundant in nature, by-products or waste materials from industry [4]. Clay minerals such as kaolinite, montmorillonite, vermiculite and illite are potential adsorbents of heavy metals. They have several economic advantages and intrinsic characteristics, e.g. are readily available, inexpensive, have excellent textural and surface properties, are physically and chemically stable in harsh environments as well as offer a cost-effective alternative to the conventional treatment of wastewater [5]. The aim of this study is to investigate the removal of nickel ions from wastewater produced by petroleum refineries using calcined kaolin clay from Alkaleri in North-East Nigeria.

\section{Materials and Methods}

\subsection{Beneficiation and calcination of samples}

$10 \mathrm{~kg}$ of raw kaolin clay was crushed and soaked in water for 24 hours. The clay-water mixture was plunged for 3 
hours at room temperature. Colloidal kaolin clay was separated from the quartz-rich sediment and sieved through a 230 mesh Tyler sieve to remove other coarse impurities. The thickened clay was then put in a filter cloth and pressed under hydraulic pressure to squeeze out the water. The cake was dried in an oven at $110^{\circ} \mathrm{C}$ to constant weight before being pulverized.

$100 \mathrm{~g}$ of the beneficiated clay was fired gradually in an electric furnace at $650{ }^{\circ} \mathrm{C}$ for 3 hours before being soaked. The calcined clay adsorbent was cooled, characterized and used for adsorption experiments.

\subsection{Batch Adsorption}

The wastewater used of a known initial concentration of nickel ions was obtained from the effluent of a petroleum refinery operated by Kaduna Refining and Petrochemicals Company. The batch experiments were conducted by varying the adsorbent mass, contact time and temperature as described. The effect of the adsorbent mass was determined at $25^{\circ} \mathrm{C}$ and $0.5 \mathrm{~g}$ of oven-dried calcined kaolin was mixed with $50 \mathrm{~mL}$ of wastewater in a $250 \mathrm{~mL}$ Erlenmeyer flask. The mixture was stirred with a magnetic stirrer at $200 \mathrm{rpm}$ for between 10 and 50 mins. The process was repeated by varying the adsorbent mass in increments of $0.5 \mathrm{~g}$, namely $1.0,1.5,2.0$ and $2.5 \mathrm{~g}$. The effect of the contact time was analyzed using $0.5 \mathrm{~g}$ of adsorbent after $10,20,30,40$ and 50 mins. The effect of the temperature was investigated within the range of $25-65^{\circ} \mathrm{C}$ following a contact time of 30 mins. with adsorbent masses of 0.5 and $2.5 \mathrm{~g}$. The residual $\mathrm{Ni}$ (II) ions obtained from the filtrate and determined by Atomic Absorption Spectroscopy (AAS) were analyzed to evaluate the percentage removal, adsorption kinetics and thermodynamics.

\section{Results and Discussion}

\subsection{Characterization of the adsorbent}

\section{Chemical composition}

The chemical composition of the adsorbent is shown in Table 1. The main components of the clay are $\mathrm{SiO}_{2}$ (53.158 wt \%) and $\mathrm{Al}_{2} \mathrm{O}_{3}$ (41.143 wt \%). Metallic oxides such as $\mathrm{TiO}_{2}, \mathrm{MgO}$ and $\mathrm{Fe}_{2} \mathrm{O}_{3}$ are present in small amounts, while traces of $\mathrm{CaO}, \mathrm{Cr}_{2} \mathrm{O}_{3}, \mathrm{ZnO}$ and $\mathrm{Mn}_{2} \mathrm{O}_{3}$ are detected.

The large amounts of $\mathrm{SiO}_{2}$ and $\mathrm{Al}_{2} \mathrm{O}_{3}$ present define the sample as an aluminosilicate clay. Generally speaking, kaolin clay, the chemical formula of which is $\mathrm{Al}_{2} \mathrm{Si}_{2} \mathrm{O}_{5}(\mathrm{OH})_{4}$, is principally composed of $\mathrm{SiO}_{2}, \mathrm{Al}_{2} \mathrm{O}_{3}$ and water [6].

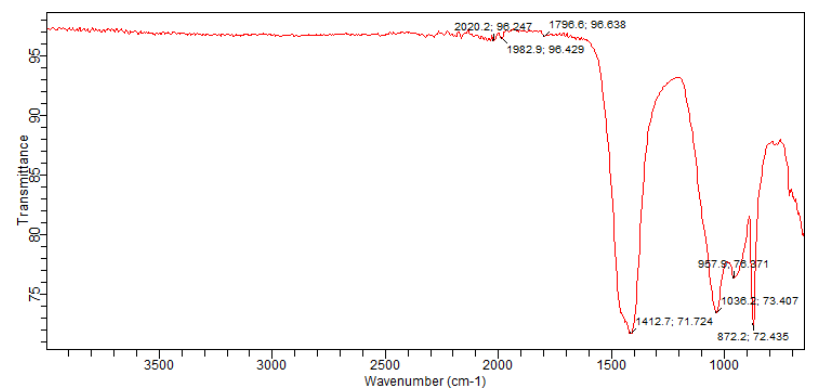

Figure 1: Fourier-transform infrared spectrum of calcined kaolin clay

\section{Fourier-transform infrared spectroscopy}

Fourier Transform InfraRed spectroscopy (FTIR) shows the functional groups present in the sample of clay. The FTIR spectra of the kaolin clay shown in Fig. 1 are within the wavenumber range of $4000-400 \mathrm{~cm}^{-1}$. The spectra depict three major absorption bands, namely silicon dioxide, alumina and hydroxyl groups. The peaks at 1030 , 1045 and $1049 \mathrm{~cm}^{-1}$ are assigned to the stretching vibrations of the $\mathrm{Si}-\mathrm{O}$ bond and the peak observed at 922 $\mathrm{cm}^{-1}$ corresponds to the Al-Al-OH bonds. Peaks at 733 , 750 and $752 \mathrm{~cm}^{-1}$ indicate the presence of $\mathrm{OH}$ resulting from the expulsion of water and hydroxyl groups in clay minerals during calcination [7]. The differences in the peak intensities can be attributed to the interaction of $\mathrm{Ni}(\mathrm{II})$ ions with functional groups on the kaolin adsorbent surface [8].

\subsection{Adsorption studies}

\section{Effect of adsorbent mass}

The adsorbent mass plays a vital role in adsorption processes. It determines the percentage removal of metal ions and is calculated by:

$$
\% \operatorname{Ads}=\frac{c_{\mathrm{i}}-c_{\mathrm{f}}}{c_{\mathrm{i}}}
$$

where $\%$ Ads denotes the amount of $\mathrm{Ni}(\mathrm{II})$ ions removed, and $c_{\mathrm{i}}$ and $c_{\mathrm{f}}$ stand for the initial and final concentrations (ppm) of the $\mathrm{Ni}$ (II) ions, respectively. The percentage removal of $\mathrm{Ni}$ (II) ions increased from 76.31 to $89.04 \%$ when the adsorbent mass was increased from 0.5 to 2.5 $\mathrm{g}$ as shown in Fig. 2. As the adsorbent mass increases, more adsorption sites of nickel ions become available.

\section{Effect of contact time on the uptake of nickel ions}

The adsorption isotherm describes the adsorption pattern between the $\mathrm{Ni}$ (II) ions adsorbed on the kaolin clay and

Table 1: Chemical composition of the calcined kaolin sample

\begin{tabular}{cccccccccc}
\hline Components & $\mathrm{SiO}_{2}$ & $\mathrm{Al}_{2} \mathrm{O}_{3}$ & $\mathrm{TiO}_{2}$ & $\mathrm{MgO}$ & $\mathrm{Fe}_{2} \mathrm{O}_{3}$ & $\mathrm{CaO}$ & $\mathrm{Cr}_{2} \mathrm{O}_{3}$ & $\mathrm{ZnO}$ & $\mathrm{Mn}_{2} \mathrm{O}_{3}$ \\
Amount (wt \%) & 53.158 & 41.143 & 3.017 & 0.442 & 0.126 & 0.044 & 0.018 & 0.013 & 0.008 \\
\hline
\end{tabular}




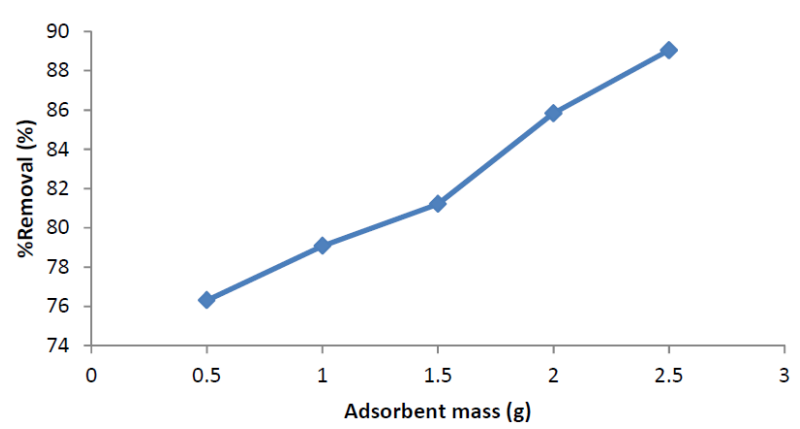

Figure 2: Effect of adsorbent mass on the removal of nickel ion

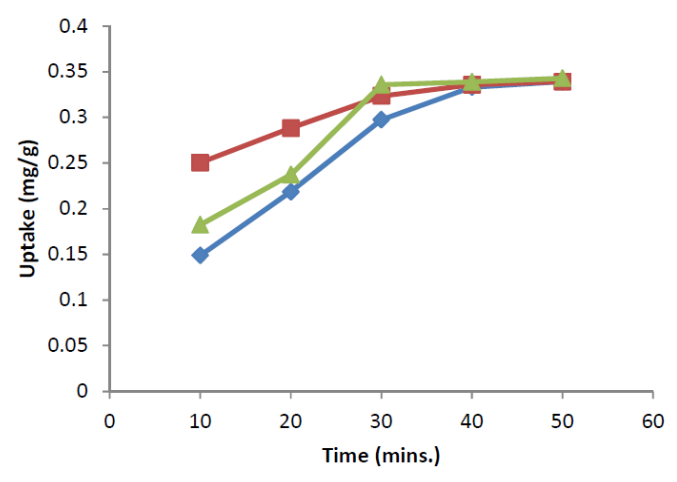

Figure 3: Effect of contact time on the uptake of nickel ions

the residual ions. The equilibrium uptake was determined using:

$$
q_{\mathrm{e}}=\frac{\left(c_{\mathrm{i}}-c_{\mathrm{e}}\right) V}{m}
$$

where $c_{\mathrm{e}}$ denotes the equilibrium concentration, $V$ stands for the volume of the solution and $m$ represents the adsorbent mass.

Fig. 3 shows that the uptake of nickel ions is increased by increasing the contact time and reaches a maximum or saturation point after 30 to 40 mins., and thereafter the rate of adsorption remains almost constant even as the contact time and adsorbent mass are further increased.

The extent of the adsorption of nickel ions initially increased rapidly and then gradually until an equilibrium was attained. The high removal rate was due to the large surface area initially available for adsorption of $\mathrm{Ni}$ (II) ions but the capacity of the adsorbent was gradually exhausted over time since the occupation of the few vacant surface sites that remained was inhibited due to repulsive forces between the solute molecules in the solid and bulk phases [9]. As the adsorption sites on the surface become exhausted, the uptake rate is controlled by the rate at which the nickel ions are transported from the exterior to the interior sites of the adsorbent particles [10]. It was reported that during the adsorption of metal ions, initially the $\mathrm{Ni}$ (II) ions reach the boundary layer; then have to diffuse onto the surface of the adsorbent and finally, must diffuse into its porous structure. Therefore, this process requires a relatively longer contact time [11].

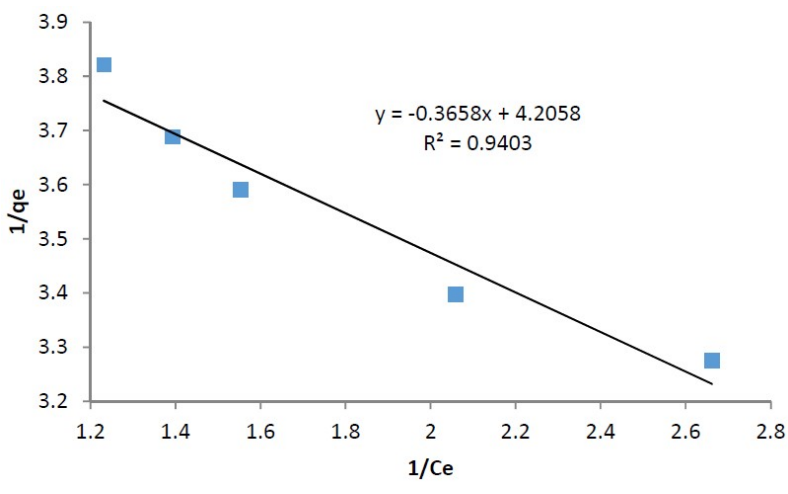

Figure 4: Langmuir isotherm for the adsorption of nickel ions

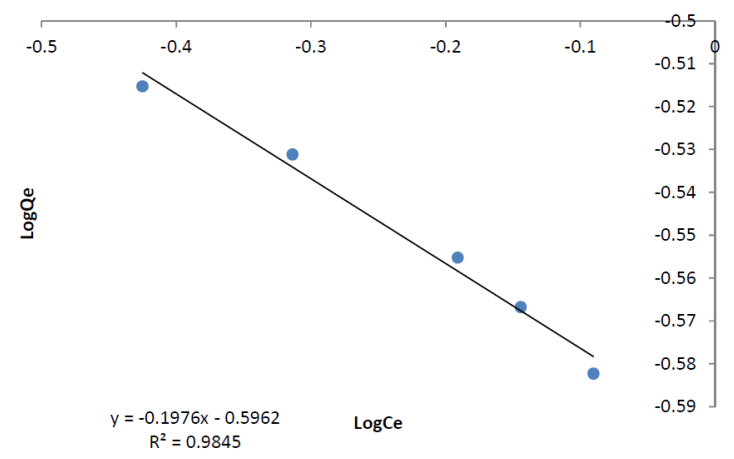

Figure 5: Freundlich isotherm for the adsorption of nickel ions

\subsection{Equilibrium isotherms}

The Langmuir and Freundlich models describe this isotherm:

$$
\frac{1}{q_{\mathrm{e}}}=\frac{1}{q_{\mathrm{m}}}+\frac{1}{q_{\mathrm{m}} b c_{\mathrm{e}}}
$$

and

$$
\log q_{\mathrm{e}}=\log K_{\mathrm{F}}+\frac{1}{n} \log c_{\mathrm{e}},
$$

where $q_{\mathrm{e}}$ denotes the uptake of $\mathrm{Ni}(\mathrm{II})$ ions adsorbed on the clay $(\mathrm{mg} / \mathrm{g}), q_{\mathrm{m}}$ and $b$ stand for the single-layer adsorption capacity $(\mathrm{mg} / \mathrm{g})$ and the Langmuir equilibrium constant (L/mg), respectively, and $K_{\mathrm{F}}, n$ and $b$ represent Freundlich adsorption constants.

The Langmuir and Freundlich constants shown in Table 2 were determined from the gradients and intercepts using the equations displayed in Figs. 4 and 5. The magnitudes of $K_{\mathrm{F}}$ and $n$ are $0.2535(\mathrm{mg} / \mathrm{g})(\mathrm{L} / \mathrm{mg})^{1 / n}$ and $-5.08 \mathrm{~L} / \mathrm{mg}$, respectively. The constant, $n$, is related to the ionic strength with regard to the adsorption of $\mathrm{Ni}$ (II) ions and $K_{\mathrm{F}}$ is related to both the ionic strength and amount of $\mathrm{Ni}(\mathrm{II})$ ions adsorbed. The significance of $n$ is as follows: $n<1$ (chemical process); $n=1$ (linear process) and $n>1$ (physical process). The negative value of $n(-5.08 \mathrm{~L} / \mathrm{mg})$ obtained is indicative of chemical adsorption [12].

The Langmuir constant, $b$, shows the affinity of binding sites for nickel ions of the adsorbent. Similarly, the 
Table 2: Parameters of Freundlich and Langmuir isotherm models

\begin{tabular}{ccc}
\hline \multicolumn{3}{c}{ Freundlich Model } \\
$n(\mathrm{~L} / \mathrm{mg})$ & $K_{\mathrm{F}}(\mathrm{mg} / \mathrm{g})(\mathrm{L} / \mathrm{mg})^{1 / n}$ & $R^{2}(\%)$ \\
-5.08 & 0.2535 & 98.40 \\
& Langmuir Model \\
$q_{\mathrm{m}}(\mathrm{mg} / \mathrm{g})$ & $b(\mathrm{~L} / \mathrm{mg})$ & $R^{2}(\%)$ \\
0.2378 & -11.5210 & 94.00 \\
\hline
\end{tabular}

Table 3: Pseudo-kinetics constants for the adsorption of nickel onto calcined kaolin

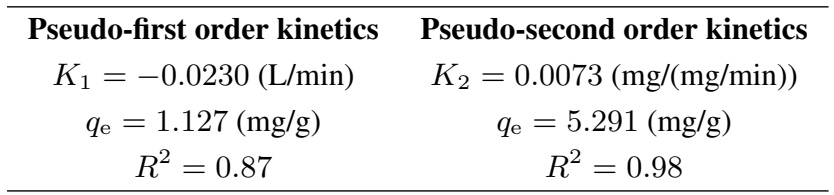

negative value of $b(-11.5210 \mathrm{~L} / \mathrm{mg})$ suggests a low degree of adsorption of $\mathrm{Ni}$ (II) ions by kaolin clay as is shown by the maximum adsorption capacity, $q_{\mathrm{m}}(0.2378$ $\mathrm{mg} / \mathrm{g})$. The experimental data fitted well in the Freundlich model $\left(R^{2}=98.40 \%\right)$ indicating multilayer adsorption on the heterogeneous surface.

\subsection{Adsorption kinetics}

The kinetics data were determined using the linear equations of pseudo-first and second order kinetics:

$$
\log \left(q_{\mathrm{e}}-q_{t}\right)=\log q_{\mathrm{e}}-\frac{1}{2.303} K_{1} t
$$

and

$$
\frac{t}{q_{t}}=\frac{1}{K_{2} q_{\mathrm{e}}^{2}}+\frac{t}{q_{\mathrm{e}}}
$$

The parameters of adsorption kinetics are useful to predict the adsorption rate and provide considerable information to design and model the adsorption process as well as evaluate the adsorbent and operation control [13]. Figs. 6 and 7 showed pseudo-first and second order kinetics, respectively with regard to the adsorption of $\mathrm{Ni}$ (II) ions. The kinetics constants are summarized in Table 3 .

The pseudo-first order kinetics exhibit a higher rate constant $\left(K_{1}\right)$ and lower uptake $\left(q_{\mathrm{e}}\right)$. According to the values of $R^{2}$ in Table 3, it is clear that pseudo-second order kinetics fitted better to the adsorption data. This suggests the adsorption process is controlled by a chemisorption mechanism and the rate-limiting step is probably the surface adsorption of nickel ions [5].

\subsection{Adsorption thermodynamics}

The effect of temperature on the adsorption of nickel ions was investigated between 25 and $65^{\circ} \mathrm{C}$. The thermodynamic parameters determined from equations

$$
K_{c}=\frac{q_{\mathrm{e}}}{c_{\mathrm{e}}}
$$

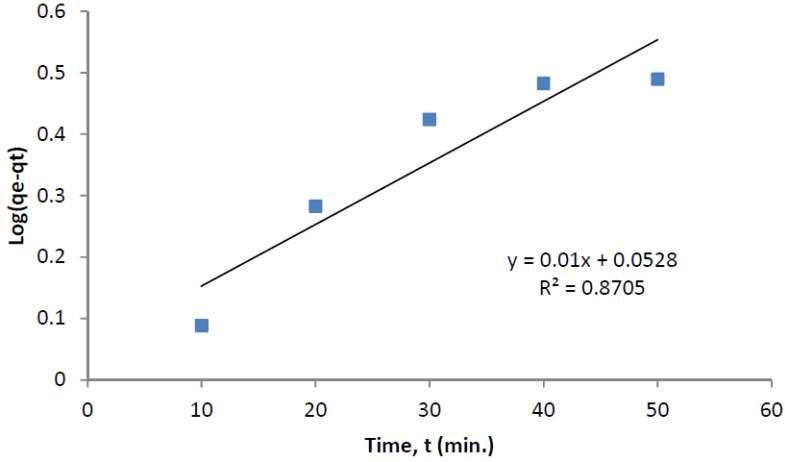

Figure 6: Pseudo-first order kinetics for the adsorption of nickel ions onto calcined kaolin clay

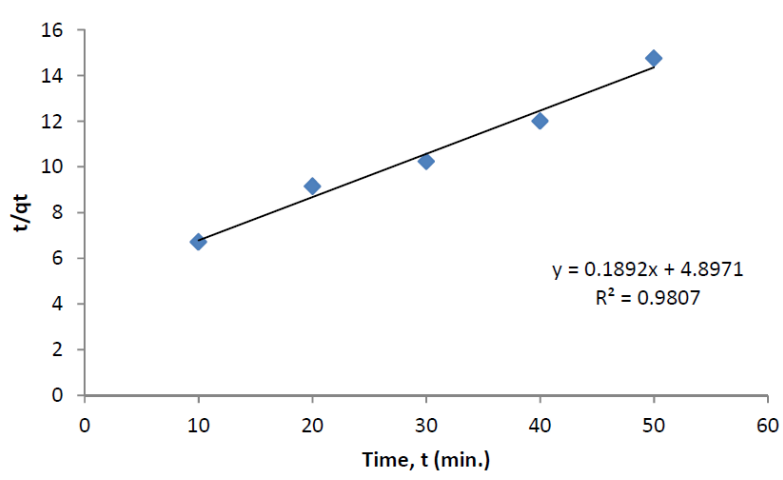

Figure 7: Pseudo-second order kinetics for the adsorption of nickel ions onto calcined kaolin clay

$$
\begin{gathered}
\Delta G^{\circ}=-R T \ln K_{c} \\
\ln K_{c}=-\frac{\Delta H^{\circ}}{R T}+\frac{\Delta S^{\circ}}{R} \\
\Delta G^{\circ}=\Delta H^{\circ}-T \Delta S^{\circ}
\end{gathered}
$$

include changes in Gibbs free energy $\left(\Delta G^{\circ}\right)$, enthalpy $\left(\Delta H^{\circ}\right)$ and entropy $\left(\Delta S^{\circ}\right)$. Fig. 8 depicts the Van't Hoff plots used to evaluate the thermodynamic parameters summarized in Table 4 . The negative values of $\Delta G^{\circ}$ confirm that the adsorption process is feasible and spontaneous while the positive values of $\Delta H^{\circ}$ show that the adsorption process of $\mathrm{Ni}(\mathrm{II})$ ions is endothermic.

$\Delta H^{\circ}$ can indicate the type of adsorption process involved. If $\Delta H^{\circ}$ of the adsorbent exceeds 40 or is less than $20 \mathrm{~kJ} / \mathrm{mol}$, chemisorption or adsorption that is physical in nature occurs, respectively [8]. The positive values of $\Delta H^{\circ}$ and $\Delta S^{\circ}$ obtained show that the adsorption process is physical in nature and the solid-aqueous solution interface becomes more irregular and random during the adsorption of $\mathrm{Ni}(\mathrm{II})$ ions by the calcined kaolin adsorbent.

\section{Conclusions}

Thermally activated kaolin clay as an adsorbent was successfully prepared by calcination and used to remove 


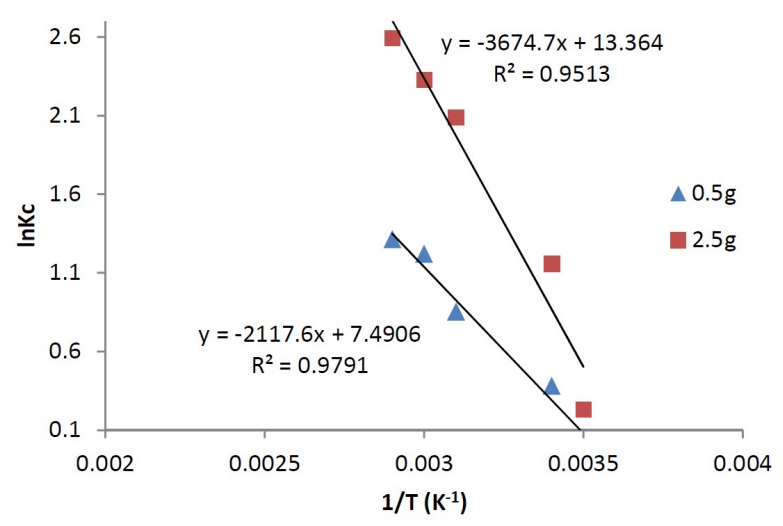

Figure 8: Effect of temperature with regard to the adsorption of nickel (II) ions on calcined kaolin

Table 4: Thermodynamic parameters for the adsorption of nickel (II) ions onto calcined kaolin at $25^{\circ} \mathrm{C}$

\begin{tabular}{lllll}
\hline $\begin{array}{l}\text { Adsorbent } \\
\text { mass }(\mathrm{g})\end{array}$ & $\begin{array}{l}\Delta G^{\circ} \\
(\mathrm{J} / \mathrm{mol})\end{array}$ & $\begin{array}{l}\Delta S^{\circ} \\
(\mathrm{J} / \mathrm{mol} \mathrm{K})\end{array}$ & $\Delta H^{\circ}(\mathrm{J} / \mathrm{mol})$ & $R^{2}$ \\
\hline 0.5 & -875.26 & 62.27 & 17600.74 & 0.979 \\
2.5 & -2553.22 & 111.07 & 30545.64 & 0.951 \\
\hline
\end{tabular}

nickel ions from wastewater produced by a petroleum refinery. Adsorption isotherms, kinetics and thermodynamics were also studied. It was discovered that the adsorbent mass, contact time and temperature significantly influenced the adsorption of nickel ions onto the calcined kaolin adsorbent. The removal efficiency was increased by increasing the adsorbent mass, contact time and temperature. The adsorption data were described well by a Freundlich isotherm and pseudo-second order kinetics fitted well to the adsorption process. The negative values of $\Delta G^{\circ}$ indicated that the adsorption of nickel ions was feasible and spontaneous. The positive values of $\Delta H^{\circ}$ showed that the process was endothermic and irreversible. Generally speaking, the results revealed that calcined kaolin is a potential adsorbent for the treatment of wastewater laden with nickel ions produced by petroleum refineries.

\section{REFERENCES}

[1] Padmavathy, K. S.; Madhu, G.; Haseena, P. V.: A study on effects of $\mathrm{pH}$, adsorbent dosage, time, initial concentration and adsorption isotherm study for the removal of hexavalent chromium $(\mathrm{Cr}(\mathrm{VI}))$ from wastewater by magnetite nanoparticles. Procedia Technol., 2016, 24, 585-594 DOI: 10.1016/j.protcy.2016.05.127

[2] Zubir, M. H. M.; Zaini, A. A. M.: Twigsderived activated carbons via $\mathrm{H}_{3} \mathrm{PO}_{4} / \mathrm{ZnCl}_{2}$ composite activation for methylene blue and congo red dyes removal. Sci. Rep., 2020, 10(1), 14050 DOI: 10.1038/s41598-020-71034-6

[3] Es-sahbany, H.; Berradi, M.; Nkhili, S.; Hsissou, R.; Allaoui, M.; Loutfi M.; Bassir, D.; Belfaquir, M;
El Youbi, S. M.: Removal of heavy metals (nickel) contained in wastewater-models by the adsorption technique on natural clay. Mater. Today: Proc., 2019, 13(3), 866-875 DOI: 10.1016/j.matpr.2019.04.050

[4] Alhawas, M.; Alwabel, M.; Ghoneim, A.; Alfarraj, A; Sallam, A.: Removal of nickel from aqueous solution by low-cost clay adsorbents. Proc. Int. Acad. Ecol. Env. Sci., 2013, 3(2), 160169 http://www.iaees.org/publications/ journals/piaees/articles/2013-3(2) /removal-of-nickel-from-aqueous-solution. $\operatorname{pdf}$

[5] Jock, A. A.; Muhammad, A. A. Z.; Abdulsalam, S.; El-Nafaty, U. A.; Aroke, U. O.: Insight into kinetics and thermodynamics properties of multicomponent lead(II), cadmium(II) and manganese(II) adsorption onto Dijah-Monkin bentonite clay. Part. Sci. Technol., 2018, 36(5), 569-577 DOI: 10.1080/02726351.2016.1276499

[6] Jongs, S. L.; Jock, A. A.; Ekanem, E. O.; Jauro, A.: Statistical analysis on physico-chemical properties of some Nigerian clay deposits. J. Mat. Sci. Chem. Eng., 2019, 7(8), 52-63 DOI: 10.4236/msce.2019.78007

[7] Jock, A. A.; Muhammad, A. A. Z.; Abdulsalam, S.; El-Nafaty, U. A.; Aroke, U. O.: Physicochemical characteristics of surface modified Dijah-Monkin bentonite. Part. Sci. Technol., 2016, 36(3), 287-297 DOI: 10.1080/02726351.2016.1245689

[8] Gorzin, F.; Abadi, M. M. B. R.: Adsorption of $\mathrm{Cr}$ (VI) from aqueous solution by adsorbent prepared from paper mill sludge: Kinetics and thermodynamics studies. Adsorp. Sci. Technol., 2018, 36(1-2), 149-169 DOI: 10.1177/0263617416686976

[9] Kumar, P. S.; Sivaprakash, S.; Jayakumar, N.: Removal of methylene blue dye from aqueous solutions using Lagerstroemia indica seed (LIS) activated carbon. Int. J. Mat. Sci., 2017, 12(1), 107116 https://www.ripublication.com/ijoms17/ ijomsv12n1_12.pdf

[10] Alzaydien, A. S.: Adsorption behavior of methyl orange onto wheat bran: Role of surface and pH. Orient. J. Chem., 2015, 31(2), 643-651 DOI: 10.13005/ojc/310205

[11] Khodaie, M.; Ghasemi, N.; Moradi, B; Rahimi, M.: Removal of methylene blue from wastewater by adsorption onto $\mathrm{ZnCl}_{2}$ activated corn husk carbon equilibrium studies. J. Chem., 2013, 2013, 1-6 DOI: 10.1155/2013/383985

[12] Marrakchi, F.; Hameed, B. H.; Hummadi, E. H.: Mesoporous biohybrid epichlorohydrin crosslinked chitosan/carbon-clay adsorbent for effective cationic and anionic dyes adsorption. Int. J. Biol. Macromol., 2010, 163, 1079-1086 DOI: 10.1016/j.ijbiomac.2020.07.032

[13] Deniz, F.: Adsorption properties of low-cost biomaterial derived from Prunus amygdalus L. for dye removal from water. Sci. World J., 2013, 2013, 1-8 DOI: $10.1155 / 2013 / 961671$ 